\title{
Characterization of sterolic and alcoholic fractions of some Algerian olive oils according to the variety and ripening stage
}

\author{
Hasna Boulkroune ${ }^{1, *}$, Aida Lazzez ${ }^{2}$, Mokhtar Guissous ${ }^{1}$, Yuva Bellik ${ }^{1}$, Sami Smaoui ${ }^{2}$, \\ Naziha Grati Kamoun ${ }^{2}$ and Toufik Madani ${ }^{3}$ \\ ${ }^{1}$ Department of Biology, Faculty of Life and Nature Sciences, Mohamed El Bachir El Ibrahimi University, Bordj Bou Arreridj 34000, \\ Algeria \\ 2 Laboratory of Technology and Quality, Olive Tree Institute, BP 1087, Sfax, Tunisia \\ ${ }^{3}$ Laboratory of Natural Resources Characterization, Setif, Algeria
}

Received 14 October 2016 - Accepted 25 April 2017

\begin{abstract}
The present study reported for the first time the evolution of some minor compounds (sterols and aliphatic alcohols) composition of four Algerian olive oils according to the cultivar and the maturity stage during the season (2013/2014). Olive samples were collected during eight different harvesting dates. The studied cultivars were Chemlal, Aghenfas, Buichret and Mekki. Ten sterolic compounds, triterpene dialcohols (erythrodiol + uvaol) and seven fatty alcohols were identified and characterized. The results showed a decreasing level of total sterols, $\beta$-sitosterol, triterpenic dialcohols, total aliphatic alcohols, tetracosanol (C24), and an increasing level of $\Delta^{5}$-avenasterol according to the maturity process. Linear discriminant analysis (LDA) enabled the classification of the studied varieties on the basis of analytical data and a correct classification rate of $96.5 \%$ and $88.6 \%$ was achieved using the original and cross validation method respectively. The most discriminating variables have been: cholesterol, campestanol, $\Delta^{7}$-stigmastenol, $\Delta^{7}$-avenasterol, clerosterol, alcohol C22, alcohol C25, alcohol C27.
\end{abstract}

Keywords: minor compounds / olive oil / cultivar / maturity / discriminant analysis

Résumé - Caractérisation des fractions stéroliques et alcooliques de quelques huiles d'olive algériennes en fonction de la variété et de l'état de maturité. Cette étude rapporte pour la première fois l'évolution de la composition en stérols et alcools aliphatiques de quatre huiles d'olive algériennes en fonction du cultivar et de la maturité au cours de la récolte 2013/2014. Les échantillons d'olives ont été collectés à huit dates de récolte différentes. Les cultivars étudiés sont: Chemlal, Aghenfas, Buichret et Mekki. Dix composés stéroliques, deux dialcools triterpéniques (érythrodiol + uvaol) et sept alcools gras ont été identifiés et caractérisés. Les résultats ont montré une teneur décroissante pour les stérols totaux, le $\beta$-sitostérol, les dialcools triterpéniques, les alcools aliphatiques totaux et le tétracosanol (C24) et inversement une teneur croissante en $\Delta 5$-avénastérol avec l'augmentation progressive de la maturité. L'analyse linéaire discriminante (linear discriminant analysis [LDA]) a permis la classification des variétés étudiées sur la base des données analytiques. Un taux de classification correct de $96,5 \%$ et 88,6\% a été atteint en utilisant respectivement les méthodes de validation originale et croisée. Les variables les plus discriminantes ont été : le cholestérol, le campestanol, le $\Delta 7$-stigmasténol, le $\Delta 7$-avénastérol, le clérostérol et les alcools gras $\mathrm{C} 22, \mathrm{C} 25$ et $\mathrm{C} 27$.

Mots clés : composés mineurs / huile d'olive / cultivar / maturité / analyse discriminante

\section{Introduction}

Olive oil is one of the most important food products throughout the Mediterranean Basin due to its high nutritional

\footnotetext{
* Correspondence: hasna34@gmail.com;

h. boulkroune@univ-bba.dz
}

and dietetic value. It is composed essentially of triacylglycerols which represent $98 \%$ of the oil and minor components such as tocopherols, phenolic compounds, alcohols and phytosterols (Bianchi, 2003). It has been demonstrated that the unsaponifiable fraction presented a beneficial therapeutic effect for human health (Abuajah et al., 2015; Cilla et al., 2015; Mahaddalkar et al., 2015). 
Qualitative and quantitative sterols analysis is one tool to characterize the quality and the category of olive oil according to the official method provided by regulation EEC No. 2568/ 1991 (European Union Commission, 2011), to detect possible fraudulent and mixtures with other vegetable oils (Monfreda et al., 2012).

Moreover, sterol esters evaluation has been proposed as useful parameter in studies related to varietal and geographical discrimination (Giacalone et al., 2015). Furthermore, alcohols are identified as highly applicable compounds for chemical authentification (Rivera del Álamo et al., 2004). It is well documented in the literature that the variation in quantitative sterolic profiles in olive oil is related to different factors like geographical origin (Manai-Djebali et al., 2012) harvesting technique, oil extraction systems, storage conditions, refining procedures (Gutiérrez et al., 2000), agronomic and climatic conditions (El Antari et al., 2000). Cultivar and maturity stage are considered among the main factors affecting sterolic composition (Lukić et al., 2013; Lazzez et al., 2008).

In Algeria, olive growing represents an ancient activity, which is very important sector notably for the rural economy, it occupies about 350000 ha (MADR, 2014) which are located mainly in the Kabilia region situated in the north of Algeria. Thirty-six varieties of olive oil had been identified by Mendil and Sebai (2006). Chemlal is considered as the most wellknown variety in Algeria, covering approximately $40 \%$ of the total Algerian olive orchard. It is distributed mainly in NorthCentral Algeria, particularly in Kabylia. Recently, it has been pointed that this variety is the predominant cultivar with the highest olive oil production, and the industrial oil yield is about $18 \mathrm{~L}$ per $100 \mathrm{~kg}$ of olives (Haddadi and Yakoub-Bougdal, 2010). To our knowledge, and after a very advanced literature review, we are confident that the first researches that have been done on the olive varieties in Algeria have been focused much more on the identification and characterization of these varieties based on the characteristics of fruit and the quantity of oil produced by each variety. In fact, there are scarce informations on chemical composition of Algerian olive oils (Douzane et al., 2012), and no published information related to the effect of cultivar or harvesting period on the sterolic and alcoholic compounds of the olive oil. Therefore, the objective of the present work is the characterization of sterol and alcohol fractions of four local Kabylian olive oil varieties: Chemlal, Mekki, Aghenfas and Buichret. The determination of the influence of cultivar and harvesting period on the profiles trends of these fractions is also studied. A multivariate statistical analysis ("principal component analysis" [PCA]) as an unsupervised method was applied to study the structure of the data and to visualize possible groups. Afterwards, a "linear discriminant analysis" (LDA) as a supervised method was applied to explain and predict an individual's belonging to a predefined class based on its characteristics measured using predictive variables.

\section{Material and methods}

\subsection{Plant material}

The study was carried out during the harvest season 2013/ 2014 in olive orchards located in Djaafra, department of Bordj Bou Arreridj, North-Eastern part of Algeria, as shown in
Figure 1. The latitude and longitude of the area are $36^{\circ} 20^{\prime} 27^{\prime \prime} \mathrm{N}$ and $4^{\circ} 46^{\prime} 3^{\prime \prime} \mathrm{E}$, respectively. Four representative autochthonous kabylian varieties were selected for this study: Aghenfas, Buichret, Chemlal and Mekki. Each variety was present in a mono-varietal orchard. The four orchards were situated approximately at an altitude of $400 \mathrm{~m}$ and characterized by the same pedo-climatic conditions, subjected to the same cultural practices and conducted without irrigation. Only healthy and fresh olive fruits were hand-picked all around the perimeter of trees. Olive samples were harvested approximately once every two weeks from the end of September until late of January. In each harvesting date, all samples varieties have nearly the same maturity index (MI) which were determined according to the Estación de Olivicultura de Jaén (Uceda and Hermoso, 2001). This method is based on the evaluation of the olive skin and pulp colors, and the values range from 0 to 7 . For each cultivar, twenty eight olive samples have been extracted separately at sampling period between September and January. The samples were immediately brought to the laboratory for oil extraction.

\subsection{Extraction of olive oils}

The olive oils were extracted using an Abencor system (MC2 Ingeniería y Sistemas S.L. Sevilla, Spain). First, a representative $3 \mathrm{~kg}$ sample of olive fruits was used for olive oil extraction as follows: deleafing, washing, and then crushing in the hammer mill. The obtained paste was well mixed at $25^{\circ} \mathrm{C}$ for $20 \mathrm{~min}$, then subjected to centrifugation at $3000 \mathrm{rpm}$ for 3 min without adding warm water. The collected oil was separated by decanting and kept in air-tight, sealed in a dark glass vials, and stored at $4{ }^{\circ} \mathrm{C}$ until analysis.

\subsection{Physicochemical analysis}

2.3.1 Determination of acidity, peroxide value, ultraviolet absorption indices

Free acidity (g oleic acid/100 g olive oil), peroxide value (PV) (meq $\mathrm{O}_{2} / \mathrm{kg}$ of olive oil) and the UV absorption for the determination of the extinction coefficients of K232 and K270 were measured following the analytical methods described in regulation EEC/2568/91. All parameters were determined in triplicate for each sample.

\subsubsection{Determination of sterols, triterpene dialcohols, and alcohols contents}

The content of sterolic and alcoholic fraction extracted from different samples was determined according to the analytical methods described in European regulation EEC 2568/91 and subsequent amendments (European Union Commission, 2011).

\subsubsection{Sterols and triterpene dialcohols analysis}

Five grams of olive oil were added to $\alpha$-cholestanol used as internal standard and then saponified with $50 \mathrm{ml}$ of potassium hydroxide in an ethanolic solution (2M). After one hour of boiling, the unsaponifiable fraction was extracted with $200 \mathrm{ml}$ of diethyl ether, purified with water and then dried by sodium sulfate and finally the diethyl ether was evaporated. Twenty 

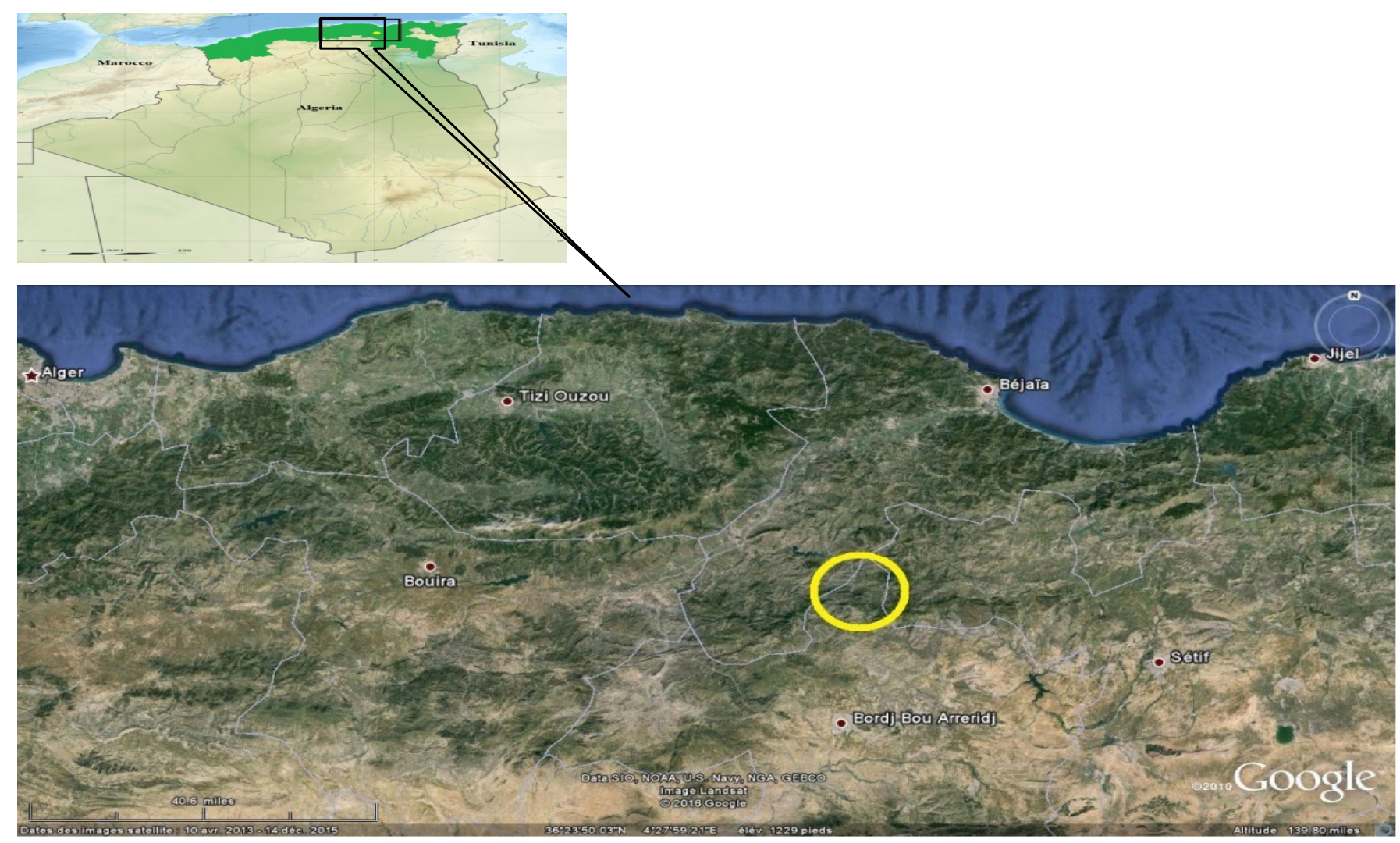

Fig. 1. Map of the studied and sampled areas.

milligrams of the unsaponifiable were dissolved in $0.5 \mathrm{ml}$ of chloroform and then deposed on a basic silica gel plate. The sterol fraction was separated by elution with a mixture of hexane and diethyl ether $(65 / 35, \mathrm{v} / \mathrm{v})$. The bands corresponding to the triterpenic dialcohols $(R f=0.21)$, sterols $(R f=0.25)$, and aliphatic alcohols $(R f=0.42)$ were scraped and the sterols recovered from the plate were dissolved in chloroform and filtered through a paper filter. As a final step, the solvent was evaporated under nitrogen and the obtained sterols were transformed into trimethylsilyl ethers by $50 \mu \mathrm{l}$ of a pyridine/ hexamethyldisilazane/trimethylchlorosilane mixture $(9 / 3 / 1, \mathrm{v} / \mathrm{v} / \mathrm{v})$.

Separation and quantification of the trimethylsilyl sterol fraction was carried out using capillary gas chromatography, on a Shimadzu set 17 A chromatograph using an HP-5 capillary column ( $30 \mathrm{~m}$ length $\mathrm{x} 0.32 \mathrm{~mm}$ i.d), coated with a stationary phase formed by $5 \%$ of biphenyl and $95 \%$ of dimethylpolysiloxane $(0.25 \mu \mathrm{m}$ thickness $)$. The working conditions of the chromatograph were as follow: type of detector: flamme ionisation detector (FID), injector temperature: $280^{\circ} \mathrm{C}$, isothermal column: $260^{\circ} \mathrm{C}$ and detector temperature: $290^{\circ} \mathrm{C}$. The injection volume was $5 \mu \mathrm{l}$ at a flow rate of $1 \mathrm{ml} / \mathrm{min}$ using nitrogen as carrier gas.

\subsubsection{Alcohols analysis}

Five grams of olive oil were added to 1-eicosanol used as internal standard and then saponified with $50 \mathrm{ml}$ of potassium hydroxide in an ethanolic solution (2M). The unsaponifiable matter was extracted with ethyl ether. The alcoholic fraction was separated from the unsaponifiable by elution on thin layer chromatography using a mixture of hexane and diethyl ether $(65 / 35, v / v)$, then the bands were scraped off and the silica gel containing the alcohols was dissolved in chloroform and filtered through a paper filter. The solvent was evaporated under nitrogen and the alcohols were treated with trimethylsilyl ethers to obtain the trimethylsilyl derivatives by $50 \mu l$ of a pyridine/hexamethyldisilazane/trimethylchlorosilane mixture $(9 / 3 / 1, \mathrm{v} / \mathrm{v} / \mathrm{v})$

The separation and quantification of the trimethyl silyl alcohol fraction was carried out using gas chromatography, on a Shimadzu set 17 A chromatograph using an HP-5 capillary column ( $30 \mathrm{~m}$ length $\times 0.32 \mathrm{~mm}$ i.d), coated with a stationary phase formed by $5 \%$ of biphenyl and $95 \%$ of dimethylpolysiloxane $(0.25 \mu \mathrm{m}$ thickness $)$. In the following conditions: the column was held at $180^{\circ} \mathrm{C}$ for 8 min then programmed to increase at $5{ }^{\circ} \mathrm{C} / \mathrm{min}$ until $260^{\circ} \mathrm{C}$ and stabilized at this temperature for $15 \mathrm{~min}$. The type of detector is FID, injector temperature: $280^{\circ} \mathrm{C}$, detector temperature: $290^{\circ} \mathrm{C}$, gas vector: nitrogen, flow rate: $1 \mathrm{ml} / \mathrm{min}$, volume injected: $5 \mu \mathrm{l}$.

The qualitative analysis of the sterolic and alcoholic fractions was performed after the determination of the retention time of their pure compounds, which had been analyzed in the same conditions.

\subsection{Statistical analysis}

All assays were carried out in triplicates and results were expressed as mean $\pm \mathrm{SD}$. Statistical analysis was carried out by using SPSS statistical package software (SPSS for windows, 
version 20, SPSS INC, and Chicago, USA). The analysis of variance (ANOVA) was applied on variables studied to detect significant differences between varieties and maturity stages. Tukey's $t$-test was then carried out to detect significant differences between values $(P<0.05)$.

Then a multivariate analysis was performed on the data set by applying PCA and LDA taking into consideration only the variables with $P<0.01$.

PCA, a commonly used multivariate method, was applied to reduce or group the large number of variables to a smaller number of new, derived variables (called principal components [PCs]). PCs are the linear combinations of the primary variables that are more conducive to making the samples different from each other. They determine which variables contribute the most to such differences.

While LDA is a multivariate probabilistic classification method based on the use of multivariate probability distribution with the hypothesis of normal distribution with the same variance-covariance matrix in all the considered classes. This chemometric technique can be used only with well-defined data matrices, i.e. those having a high ratio between number of objects and number of variables inside each category (Field, 2009).

\section{Results and discussion}

\subsection{Chemical quality criteria: acidity, peroxide value, ultraviolet absorption indices}

Table 1 shows the chemical quality criteria of olive oils from the four cultivars (Chemlal, Aghenfas, Mekki and Buichret). All the analyzed oils showed values falling within the ranges established for "extra virgin olive oil" category (acidity $\leq 0.8 \% ; \mathrm{PV} \leq 20 \mathrm{meq} \mathrm{O}_{2} / \mathrm{kg} ; \mathrm{K} 270 \leq 0.22 ; \mathrm{K} 232$ $\leq 2.5$ ), as stated by International Olive Council (IOC) (2016).

At the first harvesting date (the end of September), olive oil ripening index $(\mathrm{RI})$ of all studied varieties ranged between 1.16 and 1.31 in Buichret and Aghenfas varieties, respectively. On the seven subsequent dates, the ripening index markedly increased at 4.02 to 4.47 in Aghenfas and Chemlal varieties, respectively. These results indicate that the four varieties were characterized by the same trend of ripening process, while harvesting dates affect significantly ripening index $(P<0.0001)$.

The percentage of free acids is an important used parameter used to measure the olive oil acidity. A significant increase in free acidity along the studied varieties as ripening progressed $(P<0.0001)$ and stage of ripeness $(P<0.005)$ (Tab. 1). During the different harvesting dates, the acidity of olive oils varied from $0.1 \%$ to $0.2 \%$ in Chemlal and Buichret olive oils, and from $0.1 \%$ to $0.3 \%$ in Aghenfas and Mekki olive oils. A similar slight increase in acidity during the maturation period was found by Bengana et al. (2013). In fact, during the olive ripening, there is an increase in lipolytic activity which hydrolyses some triacylglycerols and gives fatty acids, monoacylglycerols and diacylglycerols (Martinez Suarez, 1973).

Measurements of PV and absorbance at $232 \mathrm{~nm}$ in the UV region are used to provide information on the primary oxidation of the olive oils. As it is shown in Table 1, the oils obtained from olives at more advanced ripening stages presented a decrease in the values of PV. This diminution is significant only in Buichret and Mekki olive oils in which the values varied from 9.24 and 10.07 to 5.34 and 6.50 at the first and last sampling, respectively. This behavior is most likely related to the increasing of enzymatic lipoxygenase activity. Likewise, K232 values decreased as ripening progressed, this result disagree the results found by Desouky et al. (2009).

$\mathrm{K} 270$ is considered as an indicator of secondary oxidation, as shown in Table 1 this parameter present a slight tendency to decrease during maturity process but not significantly in all studied olive oils, which can been explained by the absence of secondary oxidation during olive maturation.

\subsection{Impact of variety and maturity stage on sterolic compound trends}

The sterolic composition of olive oils of the studied varieties is given in Table 2. Figure 2 shows a chromatogram of the sterol components obtained for one of Chemlal olive oil samples. Ten sterolic compounds were identified, which are cholesterol, campesterol, campestanol, stigmasterol, clerosterol, $\beta$-sitosterol, $\Delta^{5,24}$-stigmastadienol, $\Delta^{7}$-stigmastenol, $\Delta^{7}$-avenasterol, and $\Delta^{5}$-avenasterol. From Table 2 , it can be seen that all studied olive oils varieties presented higher levels of sterol contents when comparing to the minimum limit $(1000 \mathrm{mg} / \mathrm{kg})$ established by the International Olive Oil Council for Virgin Olive Oil (IOC, 2016). In the present study, the mean of total sterol contents ranged between $1187 \mathrm{mg} / \mathrm{kg}$ to $2304 \mathrm{mg} / \mathrm{kg}$ among the four varieties. The obtained results were similar to other Mediterranean varieties, such as Chemlali and Chetoui olive oils from Tunisia, with an average contents of $2580 \mathrm{mg} / \mathrm{kg}$ and $1522 \mathrm{mg} / \mathrm{kg}$, respectively (Lazzez et al., 2008; Ben Temime et al., 2008), and Italian oils with values ranging from 979 to $1830 \mathrm{mg} / \mathrm{kg}$ (Giacalone et al., 2015).

Moreover, the total sterol contents in the studied varieties showed significant variations among olive cultivars and maturity stages $(P<0.0001)$. We noticed that the level of sterols decreased when the ripening stage increased and the contents drop between $9.59 \%$ for Mekki cultivar to $16.80 \%$ for Chemlal cultivar, when the first stage was compared with the last.

For Chemlal, the level of sterols decreased from $2170 \mathrm{mg} / \mathrm{kg}$ to $1744 \mathrm{mg} / \mathrm{kg}$ between September and December. Whereas, for $M e k k i$, the levels decreased from 1933 to $1747 \mathrm{mg} / \mathrm{kg}$ between September and January. Aghenfas olive oil presented the highest quantity of total sterols in comparison to the other varieties, which exceeded $2000 \mathrm{mg} / \mathrm{kg}$ until the end of November. The highest value was registered in September $(2304 \mathrm{mg} / \mathrm{kg})$, whereas the lowest content was recorded in January $(1972 \mathrm{mg} / \mathrm{kg})$. The low levels of sterols were observed in Buichret olive oil by comparison to other varieties.

With respect to ripening stage, there was a tendency for the sterol levels to decline with increasing ripeness index. This has been noted by other workers (Gutiérrez et al., 1999; Mariani et al., 1991), and is understood as being due to the synthesis of the sterols occurring in the first stages of development of the fruit: with ripening, the sterols become diluted as more oils are produced. 
Table 1. Ripening Index (RI) and means \pm SDs of chemical quality criteria of Aghenfas, Buichret, Chemlal and Mekki olive oils at different olives harvest dates.

\begin{tabular}{|c|c|c|c|c|c|c|c|c|}
\hline \multicolumn{9}{|l|}{ RI } \\
\hline Chemlal & $1.19 \pm 0.06^{\mathrm{a}}$ & $1.85 \pm 0.14^{\mathrm{b}}$ & $2.07 \pm 0.09^{\mathrm{b}, \mathrm{c}}$ & $2.49 \pm 0.15^{\mathrm{c}}$ & $3.38 \pm 0.20^{\mathrm{d}, \mathrm{e}}$ & $3.30 \pm 0.13^{\mathrm{d}}$ & $3.72 \pm 0.18^{\mathrm{e}}$ & $4.47 \pm 0.19^{\mathrm{f}}$ \\
\hline Buichret & $1.16 \pm 0.13^{\mathrm{a}}$ & $1.70 \pm 0.25^{\mathrm{b}}$ & $2.46 \pm 0.09^{\mathrm{c}, \mathrm{d}}$ & $2.39 \pm 0.34^{\mathrm{c}}$ & $3.41 \pm 0.40^{\mathrm{d}}$ & $3.67 \pm 0.29^{\mathrm{d}, \mathrm{e}}$ & $3.82 \pm 0.19^{\mathrm{d}, \mathrm{e}}$ & $4.35 \pm 0.21^{\mathrm{e}}$ \\
\hline Mekki & $1.26 \pm 0.17^{\mathrm{a}}$ & $1.74 \pm 0.14^{\mathrm{b}}$ & $2.17 \pm 0.26^{\mathrm{c}, \mathrm{d}}$ & $2.10 \pm 0.23^{\mathrm{c}}$ & $3.20 \pm 0.19^{\mathrm{d}}$ & $3.45 \pm 0.22^{\mathrm{d}, \mathrm{e}}$ & $3.76 \pm 0.23^{\mathrm{e}, \mathrm{f}}$ & $4.14 \pm 0.08^{\mathrm{g}}$ \\
\hline Aghenfas & $0.19 \pm 0.04^{\mathrm{a}}$ & $0.20 \pm 0.03^{\mathrm{a}}$ & $0.22 \pm 0.02^{\mathrm{a}}$ & $0.20 \pm 0.03^{\mathrm{a}}$ & $0.21 \pm 0.04^{\mathrm{a}}$ & $0.25 \pm 0.02^{\mathrm{a}, \mathrm{b}}$ & $0.30 \pm 0.01^{\mathrm{b}, \mathrm{c}}$ & $0.32 \pm 0.01^{\mathrm{c}}$ \\
\hline Buichret & $0.13 \pm 0.02^{\mathrm{a}}$ & $0.11 \pm 0.02^{\mathrm{a}}$ & $0.12 \pm 0.01^{\mathrm{a}}$ & $0.22 \pm 0.02^{\mathrm{b}}$ & $0.30 \pm 0.06^{\mathrm{c}}$ & $0.24 \pm 0.04^{\mathrm{b}}$ & $0.28 \pm 0.03^{\mathrm{b}, \mathrm{c}}$ & $0.20 \pm 0.05^{\mathrm{b}}$ \\
\hline Mekki & $0.18 \pm 0.03^{\mathrm{a}}$ & $0.22 \pm 0.02^{\mathrm{a}}$ & $0.21 \pm 0.04^{\mathrm{a}}$ & $0.23 \pm 0.05^{\mathrm{a}}$ & $0.23 \pm 0.04^{\mathrm{a}}$ & $0.29 \pm 0.06^{\mathrm{a}, \mathrm{b}}$ & $0.32 \pm 0.04^{\mathrm{b}, \mathrm{c}}$ & $0.37 \pm 0.06^{\mathrm{c}}$ \\
\hline \multicolumn{9}{|c|}{$\mathrm{PV}\left(\mathrm{meq} \mathrm{O}_{2} / \mathrm{kg}\right)$} \\
\hline Chemlal & $8.46 \pm 1.21^{\mathrm{a}, \mathrm{b}}$ & $9.17 \pm 2.11^{\mathrm{b}}$ & $8.45 \pm 2.11^{\mathrm{a}, \mathrm{b}}$ & $8.17 \pm 1.82^{\mathrm{a}, \mathrm{b}}$ & $7.82 \pm 1.84^{\mathrm{a}, \mathrm{b}}$ & $6.18 \pm 0.90^{\mathrm{a}}$ & $5.02 \pm 0.80^{\mathrm{a}}$ & $5.51 \pm 0.17^{\mathrm{a}}$ \\
\hline Chemlal & $1.83 \pm 0.12^{\mathrm{b}}$ & $1.75 \pm 0.30^{\mathrm{a}, \mathrm{b}}$ & $1.55 \pm 0.22^{\mathrm{a}, \mathrm{b}}$ & $1.31 \pm 0.15^{\mathrm{a}}$ & $1.22 \pm 0.08^{\mathrm{a}}$ & $1.32 \pm 0.14^{\mathrm{a}}$ & $1.12 \pm 0.21^{\mathrm{a}}$ & $1.08 \pm 0.12^{\mathrm{a}}$ \\
\hline Aghenfas & $1.73 \pm 0.18^{\mathrm{b}}$ & $1.82 \pm 0.24^{\mathrm{a}, \mathrm{b}}$ & $1.74 \pm 0.25^{\mathrm{a}, \mathrm{b}}$ & $1.57 \pm 0.16^{\mathrm{a}, \mathrm{b}}$ & $1.26 \pm 0.31^{\mathrm{a}}$ & $1.13 \pm 0.26^{\mathrm{a}}$ & $1.27 \pm 0.11^{\mathrm{a}}$ & $1.14 \pm 0.22^{\mathrm{a}}$ \\
\hline Buichret & $2.22 \pm 0.33^{\mathrm{a}, \mathrm{b}}$ & $2.23 \pm 0.11^{\mathrm{b}}$ & $2.14 \pm 0.18^{\mathrm{a}, \mathrm{b}}$ & $2.10 \pm 0.28^{\mathrm{a}, \mathrm{b}}$ & $1.99 \pm 0.19^{\mathrm{a}}$ & $2.03 \pm 0.21^{\mathrm{a}, \mathrm{b}}$ & $1.72 \pm 0.12^{\mathrm{a}}$ & $1.65 \pm 0.09^{\mathrm{a}}$ \\
\hline Mekki & $2.29 \pm 0.11^{\mathrm{b}}$ & $2.22 \pm 0.29^{\mathrm{a}, \mathrm{b}}$ & $2.22 \pm 0.32^{\mathrm{a}, \mathrm{b}}$ & $2.10 \pm 0.25^{\mathrm{a}}$ & $2.15 \pm 0.15^{\mathrm{a}}$ & $2.03 \pm 0.05^{\mathrm{a}}$ & $1.75 \pm 0.12^{\mathrm{a}}$ & $1.82 \pm 0.06^{\mathrm{a}}$ \\
\hline \multicolumn{9}{|l|}{$\mathrm{K}_{270}$} \\
\hline Chemlal & $0.18 \pm 0.04^{\mathrm{b}}$ & $0.16 \pm 0.03^{\mathrm{a}, \mathrm{b}}$ & $0.17 \pm 0.04^{\mathrm{a}, \mathrm{b}}$ & $0.15 \pm 0.03^{\mathrm{a}}$ & $0.14 \pm 0.01^{\mathrm{a}}$ & $0.15 \pm 0.02^{\mathrm{a}}$ & $0.11 \pm 0.02^{\mathrm{a}}$ & $0.12 \pm 0.02^{\mathrm{a}}$ \\
\hline Aghenfas & $0.16 \pm 0.03^{\mathrm{a}}$ & $0.15 \pm 0.03^{\mathrm{a}}$ & $0.15 \pm 0.01^{\mathrm{a}}$ & $0.13 \pm 0.02^{\mathrm{a}}$ & $0.11 \pm 0.06^{\mathrm{a}}$ & $0.13 \pm 0.01^{\mathrm{a}}$ & $0.12 \pm 0.04^{\mathrm{a}}$ & $0.13 \pm 0.04^{\mathrm{a}}$ \\
\hline Buichret & $0.20 \pm 0.02^{\mathrm{b}}$ & $0.19 \pm 0.02^{\mathrm{a}, \mathrm{b}}$ & $0.17 \pm 0.04^{\mathrm{a}}$ & $0.18 \pm 0.01^{\mathrm{a}, \mathrm{b}}$ & $0.15 \pm 0.03^{\mathrm{a}}$ & $0.13 \pm 0.01^{\mathrm{a}}$ & $0.15 \pm 0.02^{\mathrm{a}}$ & $0.14 \pm 0.03^{\mathrm{a}}$ \\
\hline Mekki & $0.14 \pm 0.01^{\mathrm{a}}$ & $0.14 \pm 0.03^{\mathrm{a}}$ & $0.15 \pm 0.01^{\mathrm{a}}$ & $0.14 \pm 0.03^{\mathrm{a}}$ & $0.15 \pm 0.02^{\mathrm{a}}$ & $0.13 \pm 0.05^{\mathrm{a}}$ & $0.15 \pm 0.04^{\mathrm{a}}$ & $0.13 \pm 0.03^{\mathrm{a}}$ \\
\hline
\end{tabular}

a,b,c,d Values with the same letter in the same line are not significantly different at a $95 \%$ confidence level $(P \leq 0.05)$.

In all studied oils, $\beta$-sitosterol was the most abundant phytosterol being found and its level represents more than $75 \%$ of total sterols. These results are similar to those reported by Lukić et al. (2013). Nevertheless, it is worth noting that all samples contained $\beta$-sitosterol with considerable quantities. The values ranged from $966.7 \mathrm{mg} / \mathrm{kg}$ to $2123.6 \mathrm{mg} / \mathrm{kg}$ (Tab. 2). Statistical analysis showed that the variety and harvesting period had a significant effect on the trend of $\beta$-sitosterol amounts in the studied varieties $(P<0.0001)$. The data reported in Table 2 showed a concomitant decrease of both components and total sterols during the process of maturity. In the case of Chemlal, $\beta$-sitosterol displayed a regular decrease from $1976.1 \mathrm{mg} / \mathrm{kg}$ in September to $1468.4 \mathrm{mg} / \mathrm{kg}$ at the end of December. As well, the same profile tendency is observed for the other varieties: Aghenfas (from $2123.6 \mathrm{mg} / \mathrm{kg}$ to $1556.2 \mathrm{mg} / \mathrm{kg}$ ), Mekki (from $1738.0 \mathrm{mg} / \mathrm{kg}$ to $1362.1 \mathrm{mg} / \mathrm{kg}$ ), and Buichret (from $1462.2 \mathrm{mg} / \mathrm{kg}$ to $996.7 \mathrm{mg} / \mathrm{kg}$ ). This reduction of $\beta$-sitosterol level during ripening stage was also observed by Vekiari et al. (2010).

The $\Delta^{5}$-avenasterol is the second major sterol found in the sterolic fraction. The $\Delta^{5}$-avenasterol and $\beta$-sistosterol are the typical components of the pulp of the olive (Christopoulou et al., 1996). The concentration of $\Delta^{5}$-avenasterol is important for olive oil quality, as it confers important antioxidant properties at high temperatures (Rossell, 2001).
The obtained results showed a significant differences related to the maturity stage in all evaluated samples $(P<0.0001)$. A significant increase of $\Delta^{5}$-avenasterol was recorded during the maturity process with a maximum level in January for Buichret $(174 \mathrm{mg} / \mathrm{kg})$, in the late of November for Chemlal and Aghenfas $(246 \mathrm{mg} / \mathrm{kg}$ and $315 \mathrm{mg} / \mathrm{kg}$, respectively), and at the beginning of December for Mekki (344 mg/kg) (Tab. 2).

This increase in $\Delta^{5}$-avenasterol is followed by a regular decrease until the end of maturity, except for Buichret. The increase of $\Delta^{5}$-avenasterol contents observed in the present study is in agreement with the results reported in other previous study (Lazzez et al., 2008).

A negative correlation was noted between $\beta$-sitosterol and $\Delta^{5}$-avenasterol in all studied oils: $r=-0.78$ for Chemlal, $r=-0.87$, for Aghenfas and Buichret, $r=-0.84$ for Mekki. This inverse relationship was previously reported for spanish varieties (Gutiérrez et al., 1999). Fernández-Cuesta et al. (2013) have explained this phenomenon to the fact that $\Delta^{5}$-avenasterol is the precursor of $\beta$-sitosterol.

Aghenfas showed the highest value of $\beta$-sitosterol $(92.15 \%)$ and low level of $\Delta^{5}$-avenasterol $(2.06 \%)$, whereas Mekki presented the lowest percentage of $\beta$-sitosterol $(76.46 \%)$ and important level of $\Delta^{5}$-avenasterol $(18.49 \%)$. Buichret and Chemlal presented high levels of $\beta$-sitosterol 


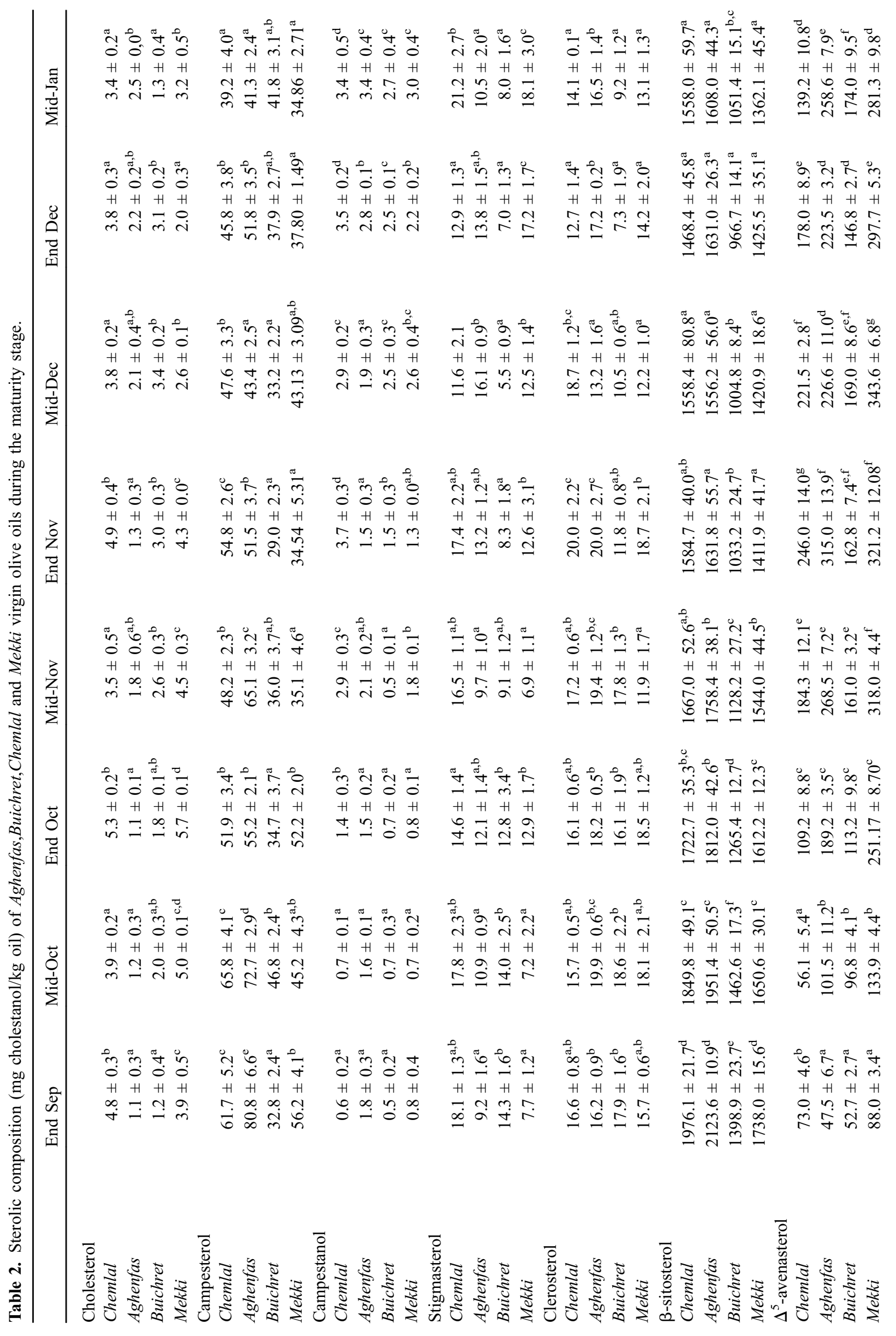


H. Boulkroune et al.: OCL 2017, 24(5), A502

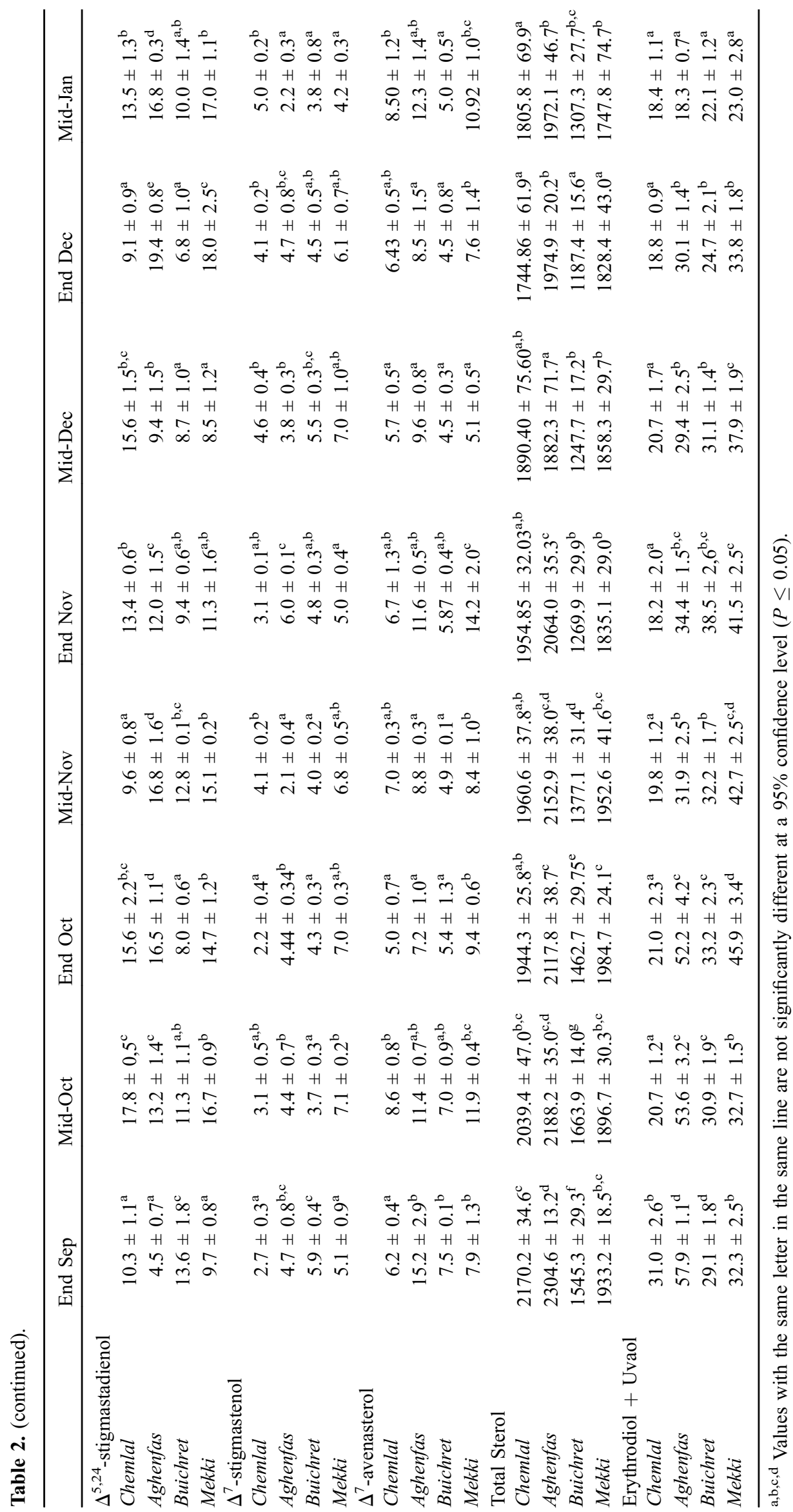

Page 7 of 14 


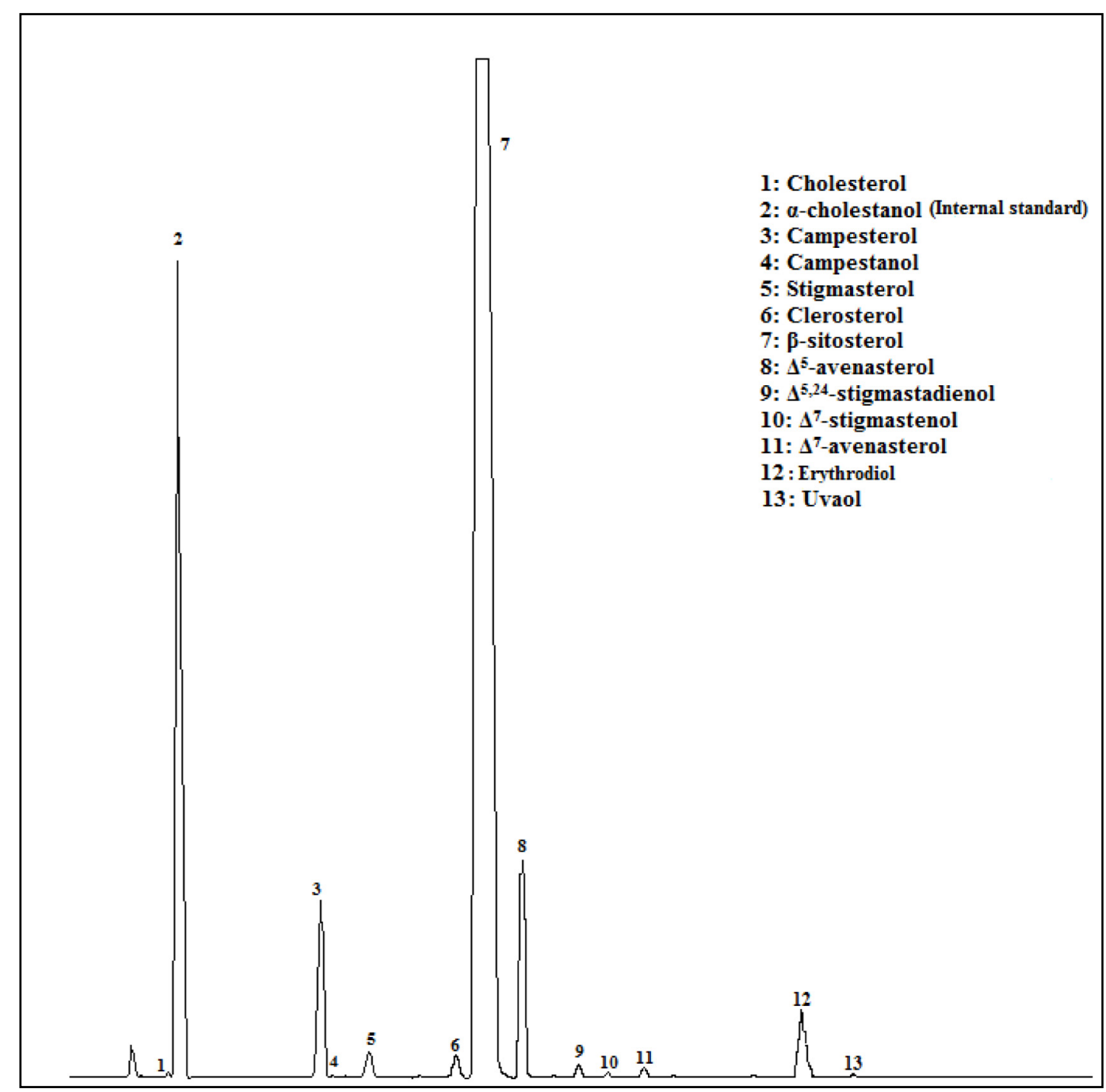

Fig. 2. Chromatogram of the sterol and triterpenic dialcohol components of one of the Chemlal analyzed samples.

$(90.53-91.06 \%)$ and low levels of $\Delta^{5}$-avenasterol (3.41$3.36 \%$ ) (data in percentage not shown in tables).

Among identified sterols, campesterol showed a low content compared to the threshold established by the IOC regulations (4\%) in all samples (IOC, 2016). As shown in Table 2, the amounts of campesterol varied significantly according to the cultivar. Furthermore, it can be observed that campesterol is significantly influenced by the maturity stage and ranged from 29 to $81 \mathrm{mg} / \mathrm{kg}$.

As well, campesterol showed a clear downward trend during the maturity process except for Buichret oil. The amounts of campesterol decreased from 80.8 to $41.3 \mathrm{mg} / \mathrm{kg}$, from 65.8 to $39.2 \mathrm{mg} / \mathrm{kg}$, and from 56.2 to $34.5 \mathrm{mg} / \mathrm{kg}$ for Aghenfas, Chemlal and Mekki olive oils, respectively. Lukić et al. (2013) have also noted a diminution in campesterol during maturation in Croatian autochthonous olive varieties.

Regarding stigmasterol amounts, all cultivars presented very low contents of stigmasterol, and the values were less than campesterol percentages, as specified by IOC regulations (2016). It is well-known that stigmasterol content evolved unlike the quality of oil, In fact, high level is associated with high acidity and low organoleptic quality of oil (Gutiérrez et al., 2000). A statistically significant difference between the studied varieties was observed $(P<0.0001)$, Chemlal variety, presented the highest value $(21.2 \mathrm{mg} / \mathrm{kg})$, whereas, Buichret presented the lowest concentration $(5.5 \mathrm{mg} / \mathrm{kg})$ of stigmasterol. During the maturity stages, the levels of stigmasterol seem to be relatively stable, excepted for the last and sixth samples respectively in Chemlal and Aghenfas oils, which represents high contents. As well, stigmasterol was constant in Buichret but decreased from the beginning of November.

Similarly, a significant difference was observed for the contents of clerosterol, which is related to the variety and the maturity $(P<0.001)$. Moderate amounts of this compounds were found, the values ranged from 7.3 to $20.0 \mathrm{mg} / \mathrm{kg}$. The contents of clerosterol found in Algerian olive oil were higher than those found by Lazzez et al. (2008), for Chemlali olive oil.

Furthermore, small amounts of cholesterol, campestanol, $\Delta^{5,24}$-stigmastadienol, $\Delta^{7}$-stigmastenol and $\Delta^{7}$-avenasterol were also identified in all analyzed olive oils. Cholesterol and $\Delta^{7}$-stigmastenol were under the limits established by the IOC regulations $(0.5 \%)$ (IOC, 2016). 


\subsection{Impact of variety and olive maturity stage on Triterpene dialcohols compounds trends}

The triterpenic dialcohols, which are the erythrodiol and uvaol are concomitantly analysed and evaluated with the sterol fraction because they are also a part of the unsaponifiable fraction. Results of the quantitative analysis of triterpenic dialcohols (erythrodiol and uvaol) of the different olive oil samples are given in Table 2. All values of triterpenic diols were in conformity with the limit established by the International Olive Oil Council's regulation for "edible virgin olive oil", which must not exceed $4.5 \%$ of the total sterols (IOC, 2016).

We noticed a significant difference among the studied varieties $(P<0.0001)$ which is in quite agreement with the findings of other studies (Sánchez-Casas et al., 2004; ManaiDjebali et al., 2012). The Aghenfas variety presented the highest levels that can reach $58 \mathrm{mg} / \mathrm{kg}$ especially in early maturity stage, while the lowest levels were observed in Chemlal variety, the other two varieties, namely Buichret and Mekki showed similar levels in most of maturity stages.

With respect to the levels of erythrodiol and uvaol during maturity process, we generally noted a downward trend when ripeness index increase. Understandably, it can be concluded that the maturity process has a significant influence on the level of the triterpenic dialcohols. These findings agree the results of Yorulmaz et al. (2013) and disagree with the outcomes found by Sánchez-Casas et al. (2004) in their study on Spanish olive oils.

\subsection{Impact of variety and olive maturity stage on alcoholic compounds trends}

The aliphatic alcohols compositions of the four varieties, Chemlal, Aghenfas, Buichret and Mekki are reported in Table 3. Figure 3 shows a chromatogram of the aliphatic alcohol components obtained for one of Chemlal olive oil samples. Seven aliphatic alcohols were identified, which are, the docosanol (C22), tricosanol (C23), tetracosanol (C24), pentacosanol (C25), hexacosanol (C26), heptacosanol (C27) and octacosanol (C28). C22, C24, C26 and C28 are the main aliphatic alcohols found in all olive oils, however, C23, C25 and $\mathrm{C} 27$ are detected in little quantities. Indeed, these compounds are located inside the olive stone, as consequence their extraction is very practical by solvent extraction methods than mechanical processes (Aparicio et al., 2013). Furthermore, the determination of these minor aliphatic alcohols is very important for the accurate knowledge of alcoholic profiles with other parameters (erythrodiol, uvaol and wax content) during the detection of possible fraudulent addition of olive pomace oil to VOO.

In the present work, the total aliphatic alcohols content varied significantly according to the variety $(P<0.05)$. The mean values of the total aliphatic alcohols ranged from $81.4 \mathrm{mg} / \mathrm{kg}$ to $315.1 \mathrm{mg} / \mathrm{kg}$. The maximum and the minimum average values were observed for Mekki olive oil (Tab. 3). Our results are similar to those found by Lazzez et al. (2008) in Chemlali olive oils, who reported values ranging between $70 \mathrm{mg} / \mathrm{kg}$ and $317 \mathrm{mg} / \mathrm{kg}$, but very higher than those observed by Rivera del Álamo et al. (2004) in Spanish olive oils, in fact the levels observed, ranged from $35.0 \mathrm{mg} / \mathrm{kg}$ to $52.6 \mathrm{mg} / \mathrm{kg}$ and from $44.2 \mathrm{mg} / \mathrm{kg}$ to $291 \mathrm{mg} / \mathrm{kg}$, respectively. Mariani et al. (1991) outlined that high content of total aliphatic alcohols in some olive oils is mainly due to the presence of aliphatic alcohols in the free (non-esterified) form rather than as waxes. This phenomenon is attributed to adverse climatic conditions (prolonged drought).

According to the obtained results, it should be noted that the total aliphatic alcohols contents were significantly affected by the ripening process $(P<0.0001)$. Aliphatic alcohols decreased significantly from early harvest period (September and beginning of October) to advanced stage of maturity (December and January). The highest values were $238.1 \mathrm{mg} / \mathrm{kg}$, $302.6 \mathrm{mg} / \mathrm{kg}, 315.1 \mathrm{mg} / \mathrm{kg}$ and $283.6 \mathrm{mg} / \mathrm{kg}$ for Chemlal, Aghenfas, Mekki and Buichret, respectively. During the maturation of olives, these values decreased progressively to reach $82.3 \mathrm{mg} / \mathrm{kg}, 86.0 \mathrm{mg} / \mathrm{kg}, 81.4 \mathrm{mg} / \mathrm{kg}$ and $115.7 \mathrm{mg} / \mathrm{kg}$ in the same order.

Hexacosanol (C26) is the most important compounds found in the alcoholic fraction in all analyzed samples. The evolution of C26 during maturity stages follow practically the evolution of total alcohols which decreased significantly during maturity. The concentrations of C26 decreased progressively, from 122.4 to $23.7 \mathrm{mg} / \mathrm{kg}$ and from 138.0 to $20.2 \mathrm{mg} / \mathrm{kg}$ for Chemlal and Mekki, respectively. Is it the same for the other two varieties, in fact, a downward trend was also recorded, as shown in Table 3 . In advanced stages of maturity, the content of $\mathrm{C} 26$ seems to be stable especially for the varieties, Mekki, Chemlal and Aghenfas. According to the variety, we noted that the high levels were recorded in Mekki oil especially at the first stages of maturity, whereas, the lowest contents were observed in the oil of Buichret. In contrast, Giuffrè (2014) showed that C26 compound is not influenced by cultivar.

Tetracosanol (C24) is considered as the second or the third most abundant alcohol, depending to the variety. The obtained results showed that $\mathrm{C} 24$ varied significantly according to the cultivar $(P<0.0005)$ and the harvest period $(P<0.0001)$. Most cultivars showed a decrease in tetracosanol contents over the ripening period. Aghenfas contained the highest quantities of C24, which was observed from September until the end of November and the concentration decreased progressively from $94.3 \mathrm{mg} / \mathrm{kg}$ in September to $18.8 \mathrm{mg} / \mathrm{kg}$ in January. For Chemlal, Mekki and Buichret olive oils, the concentrations of C24 decreased from $29.3 \mathrm{mg} / \mathrm{kg}$ to $23.1 \mathrm{mg} / \mathrm{kg}$, from $44.8 \mathrm{mg} / \mathrm{kg}$ to $37.2 \mathrm{mg} / \mathrm{kg}$, and from $65.1 \mathrm{mg} / \mathrm{kg}$ to $25.1 \mathrm{mg} / \mathrm{kg}$, respectively (Tab. 3 ).

With respect to the content of octacosanol (C28), statistical analysis showed a significant differences related to cultivar $(P<0.0001)$ and maturity stage $(P<0.0001)$. The level of $\mathrm{C} 28$ decreased clearly during maturity process for Chemlal and Buichret olive oils which the content range from $56.7 \mathrm{mg} / \mathrm{kg}$ to $11.4 \mathrm{mg} / \mathrm{kg}$ and from $44 \mathrm{mg} / \mathrm{kg}$ to $15.7 \mathrm{mg} / \mathrm{kg}$ respectively. Whereas, the concentration showed a different behavior for the other two varieties, the content of C28 increased during the first stages of maturity from $38 \mathrm{mg} / \mathrm{kg}$ to $80.5 \mathrm{mg} / \mathrm{kg}$ and decreased until the last stage of maturity for the case of Aghenfas variety. For the variety Mekki, C28 increased until reaching a maximum in October $(83.8 \mathrm{mg} / \mathrm{kg})$ and then decrease until the end of maturity. For all cultivars the concentration of octacosanol decreased at the end of the maturity process (Tab. 3), this diminution 
H. Boulkroune et al.: OCL 2017, 24(5), A502

Table 3. Alcoholic composition (mg eicosanol $/ \mathrm{kg}$ oil) of Aghenfas, Buichret, Chemlal and Mekki virgin olive oils during the maturity stage.

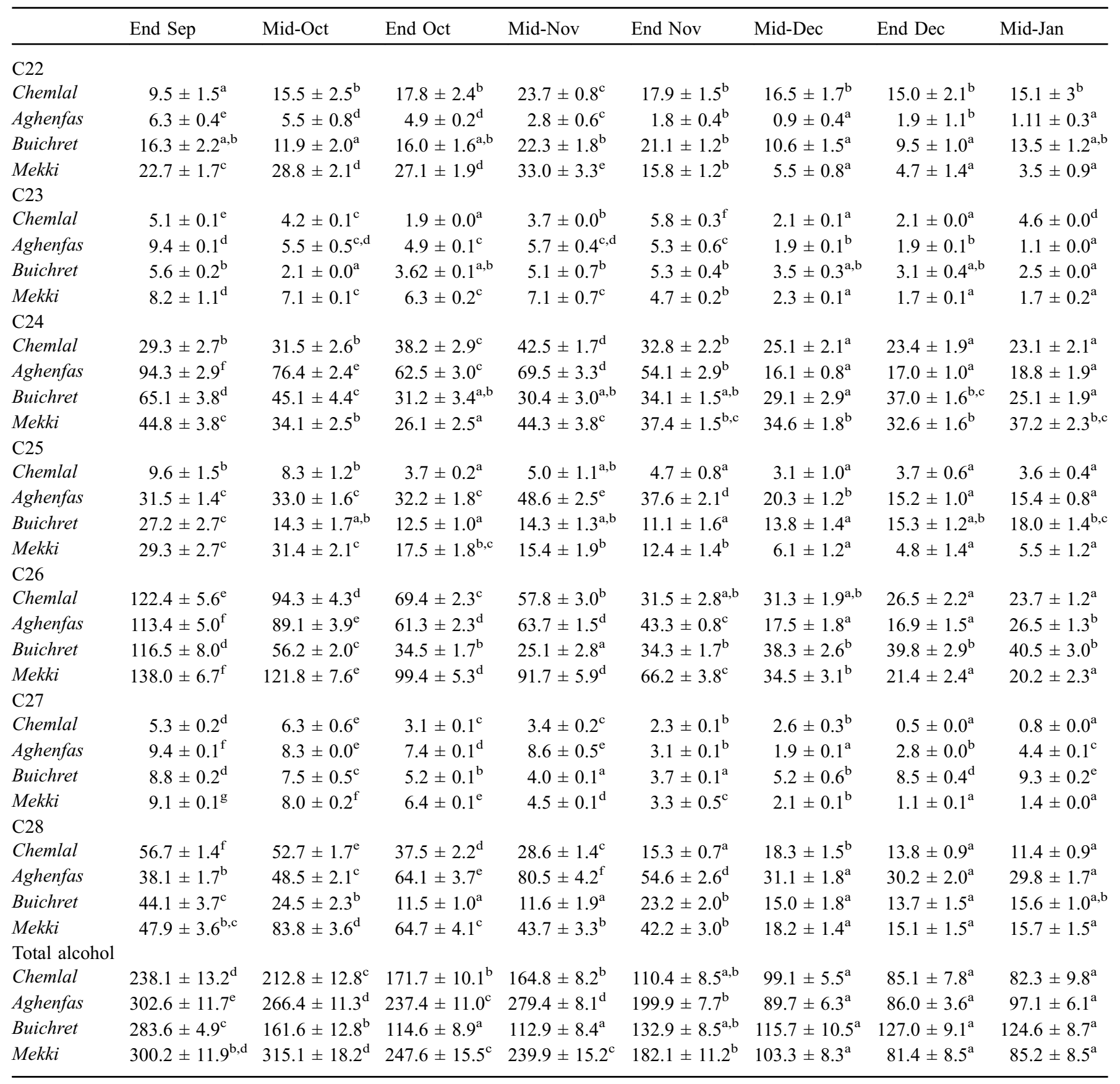

a,b,c,d Values with the same letter in the same line are not significantly different at a $95 \%$ confidence level $(P \leq 0.05)$.

was also reported in previous studies (Lazzez et al., 2008; Giuffrè, 2014).

Concerning the docosanol $\mathrm{C} 22$, all samples showed a content inferior to $33 \mathrm{mg} / \mathrm{kg}$. The concentration of docosanol (C22), ranged between $0.9 \mathrm{mg} / \mathrm{kg}$ and $33.0 \mathrm{mg} / \mathrm{kg}$. Rivera del Álamo et al. (2004), in his study reported values ranging between $8.2 \mathrm{mg} / \mathrm{kg}$ and $72.5 \mathrm{mg} / \mathrm{kg}$ for the $\mathrm{C} 22$. The obtained results, showed a significant differences according to maturity $(P<0.0001)$ and cultivar $(P<0.0001)$. During the maturation process the content of docosanol $\mathrm{C} 22$ increased and then decreased until the end of maturity, especially for the Chemlal,
Mekki and Buicheret, whereas in the oil of Aghenfas, which presented the lowest levels, we noted a decrease from $6.3 \mathrm{mg} / \mathrm{kg}$ at the first stage of maturity to a low content about $1 \mathrm{mg} / \mathrm{kg}$ at the end of maturity. In contrary, Giuffrè (2014) has found that in general samples presented a constant docosanol level through the maturity process.

Regarding the $\mathrm{C} 25$ aliphatic alcohol, the results presented in Table 3 showed that Chemlal olive oil contained the low quantities compared to the other varieties, which don't exceed $10 \mathrm{mg} / \mathrm{kg}$ in all maturity stages. However, the high quantities were found in Aghenfas variety which reached $49 \mathrm{mg} / \mathrm{kg}$ 


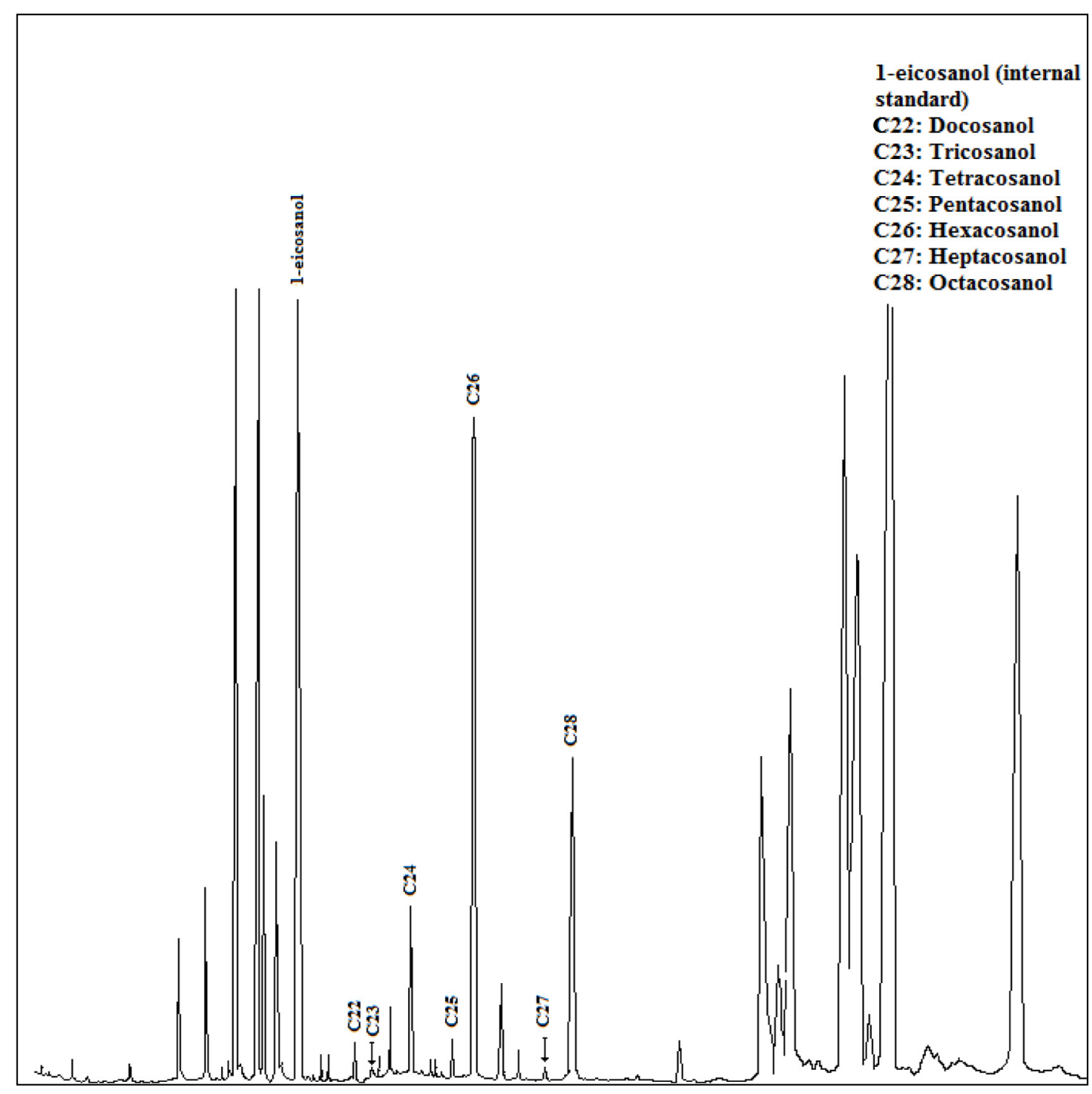

Fig. 3. Chromatogram of the aliphatic alcohol components of one of the Chemlal analyzed samples.

in November. During maturity process, the level of $\mathrm{C} 25$ decreased in the case of the following cultivars, Chemlal, Mekki and Aghenfas. We noted a richness of Algerian varieties in $\mathrm{C} 25$ content when comparing to the varieties of southern Italy, in fact, Giuffrè (2014), in his study showed a maximum content of pentacosanol with a mean of $12.7 \mathrm{mg} / \mathrm{kg}$.

With regard to $\mathrm{C} 23$, the analyzed samples showed values raging between $1.1 \mathrm{mg} / \mathrm{kg}$ and $9.4 \mathrm{mg} / \mathrm{kg}$. The autochthonous cultivars presented higher contents at the beginning of maturity and then the content of $\mathrm{C} 23$ decreased until a little value about 2 and $1 \mathrm{mg} / \mathrm{kg}$, except for Chemlal, which the content increased in January. These contents are higher than those found by Krichène et al. (2010) on Tunisian olive oils $(1.3 \mathrm{mg} / \mathrm{kg}$ to $5.3 \mathrm{mg} / \mathrm{kg})$.

Heptacosanol (C27) also showed a significant difference in relation to maturity and variety $(P<0.0001)$. The contents ranged between $0.5 \mathrm{mg} / \mathrm{kg}$ to $9.4 \mathrm{mg} / \mathrm{kg}$. In almost cultivars, heptacosanol tend to decrease during maturity process except, the Buichret variety, in which after a slight decrease in contents levels occur until the end of November, we observed an increase in the three last sampling.

\subsection{Discriminant analysis}

In order to understand which variables have a discriminating power among the four varieties, a multivariable statistical approach was applied. First we used an ANOVA test on all data, related to sterol compounds and aliphatic alcohols. The analysis of variance (ANOVA) highlighted statistically significant differences $(P<0.01)$ of all the variables, except, the stigmasterol, the $\beta$-sitosterol and the $\Delta 7$-stigmastenol. However, despite the recorded differences, after applying a post hoc test (honestly significantly different [HSD] for unequal $N$ tukey) on the obtained results, it was found that none of the used variables could perfectly classify the olive oils samples as regards to variety.

For that and in order to get a better overview of the ability of the whole set of variables to differentiate between varieties a PCA was applied. It was found that $76 \%$ of total variance was explained by four components (PCs), taking into consideration the eigenevalues and internal consistency by means of varimax rotation (Tab. 4). Selected PCs are usually discussed in terms of component scores and loadings. The four first components, 
Table 4. Loadings, eigenvalues, and percent of cumulative variance for the first four principle components.

\begin{tabular}{lrrrr}
\hline & \multicolumn{3}{c}{ Component } & \\
\cline { 2 - 5 } & 1 & 2 & 3 & \multicolumn{1}{c}{4} \\
\hline Alcohol C27 & 0.896 & 0.011 & -0.093 & 0.101 \\
Alcohol C25 & 0.712 & 0.321 & -0.364 & 0.156 \\
Campestanol & -0.694 & -0.027 & -0.280 & -0.078 \\
Alcohol C24 & 0.675 & 0.396 & -0.334 & 0.165 \\
Alcohol C23 & 0.674 & 0.367 & 0.322 & 0.335 \\
Clerosterol & 0.135 & 0.773 & 0.115 & -0.115 \\
$\Delta^{7}$-avenasterol & 0.004 & 0.708 & -0.190 & 0.444 \\
Campesterol & 0.344 & 0.707 & -0.149 & -0.274 \\
Alcohol C22 & 0.217 & -0.165 & 0.883 & 0.152 \\
Cholesterol & -0.269 & 0.074 & 0.871 & -0.042 \\
$\Delta^{7}$-stigmastenol & 0.067 & -0.194 & 0.164 & 0.885 \\
Erythrodiol and uvaol & 0.559 & 0.258 & -187 & 0.568 \\
Eigenvalues & 4.33 & 2.17 & 1.42 & 1.18 \\
\% Cumulative variance & 36.09 & 54.19 & 66.02 & 75.93 \\
\hline
\end{tabular}

called PC1 to PC4 explain respectively, PC1 (27.31\%), PC2 (17.75\%), PC3 (17.56\%) and PC4 (13.31\%) of the total variance.

The rotated component matrix showed that the $\mathrm{PC} 1$ is correlated to Campestanol, alcohols C23, C24, C25 and C27; $\mathrm{PC} 2$ is correlated to clerosterol, $\Delta^{7}$-avenasterol and campesterol. PC3 is correlated to alcohol C22 and cholesterol, PC4 is correlated to erythrodiol and uvaol and $\Delta^{7}$-stigmastenol.

The applied PCA on the variables was not sufficient to visualize possible groups between the studied olive oil varieties when the scores of olive samples displayed with respect to the three first components

As a consequence, a LDA was applied on the data as a suitable method to discriminate the olive of samples on the basis of the variety. To apply LDA, it was necessary to reduce the number of variables for the model, therefore we took into consideration only the variables with $P<0.01$ which showed significant differences between varieties.

The results showed that three statistically discriminant functions are formed (Wilk's lambda $=0.034, \chi^{2}=300.535$, $d f=24$ for the first, Wilk's lambda $=0.195, \chi^{2}=145.51, d f=14$ for the second and Wilk's lambda $=0.488, \chi^{2}=63.93, d f=6$ for the third with $P=0.000$ in all cases). The first discriminant function accounts for $69.8 \%$ of the total variance, the second accounts for $20.7 \%$ of the total variance while the third accounts for $9.5 \%$ of the total variance. All three accounts for $100 \%$ of the total variance. The variables selected by the SPSS algorithm, and the corresponding model standardized coefficients, showing the predictors with large discriminant capabilities are given in Table 5. The most discriminating variables have been: cholesterol, campestanol, $\Delta^{7}$-stigmastenol, $\Delta^{7}$-avenasterol, clerosterol, alcohol C22, alcohol C25, alcool C27.

Figure 4 showed a projection of the score corresponding to olive oil samples in the two-dimensional space defined by the first and second discriminant functions. As it is demonstrated, the VOOs from the four varieties are adequately separated. The
Table 5. Standardized canonical discriminant function coefficients.

\begin{tabular}{lrrr}
\hline & \multicolumn{2}{l}{ Function } & \\
\cline { 2 - 4 } & \multicolumn{1}{c}{1} & \multicolumn{1}{c}{3} \\
\hline Cholesterol & -0.254 & 0.817 & 0.016 \\
Campestanol & 0.207 & 0.301 & -0.530 \\
$\Delta^{7}$-stigmastenol & -0.101 & 0.308 & 0.834 \\
$\Delta^{7}$-avenasterol & 0.412 & 0.505 & 0.157 \\
Clerosterol & 0.011 & 0.324 & -0.486 \\
Alcohol C22 & -0.594 & -0.316 & -0.108 \\
Alcohol C25 & 1.185 & 0.184 & 0.011 \\
Alcohol C27 & -0.495 & -0.398 & 0.167 \\
\hline
\end{tabular}

olive oil of Chemlal, Aghenfas and Buichret are clearely separated while that of Mekki variety is adequately separated. The overall correct classification rate is $96.5 \%$ using the original and $88.6 \%$ using the cross validation method. Correct classification (100\%) was obtained for Chemlal, Aghenfas and Buichret olive oil varieties. However, Mekki is not perfectly separated from Aghenfas and Buichret which explains the $88.2 \%$ of correct classifications for Mekki cultivar.

These results are in agreement with data found in the literature; the content of sterols and alcohols in olive oils have been used for the classification of olive oils on the basis of cultivars (Lukić et al., 2013; Grati-Kammoun and Zarrouk, 2012).

The obtained results showed that the cloud point of Chemlal variety, have a negative score on the first function and positive score for the second function, means that the oils from Chemlal variety were caracterised by high value of cholesterol, clerosterol, $\Delta^{7}$-stigmastenol, alcohol C22, and alcohol C27. In the contrary, the cloud point of Aghenfas variety, have a positive score on the first function and positive score for the second function, means that the oils of Aghenfas were caracterised by high cholesterol, campestanol, $\Delta^{7}$-stigmastenol, $\Delta^{7}$-avenasterol, clerosterol and alcohol C25.

Buichret have a negative score on the first and second functions, so the oils of Buichret variety were characterized by high $\mathrm{C} 22$ and $\mathrm{C} 27$ values.

\section{Conclusion}

In general, the values of quality parameters (free acidity, peroxide value and spectrophotometric absorption K232 and K270) and those of sterolic and alcoholic compounds of four monovarietal Algerian olive oils (Aghenfas, Buichret, Chemlal and $M e k k i)$ remained within estimated limits of the International Olive Oil Council's regulation for "edible virgin olive oil" along the maturation process, which should be taken into consideration in commercial dealings and regulatory studies.

Furthermore, it has been proven that the cultivar and the ripening stage had a significant effect on the trend of several sterolic and alcoholic contents during ripening process and the results showed a decreasing level of total sterols, $\beta$-sitosterol, triterpenic dialcohols, total aliphatic alcohols, tetracosanol (C24), and an increasing level of $\Delta^{5}$-avenasterol according to the maturity process. 


\section{Canonical Discriminant Functions}
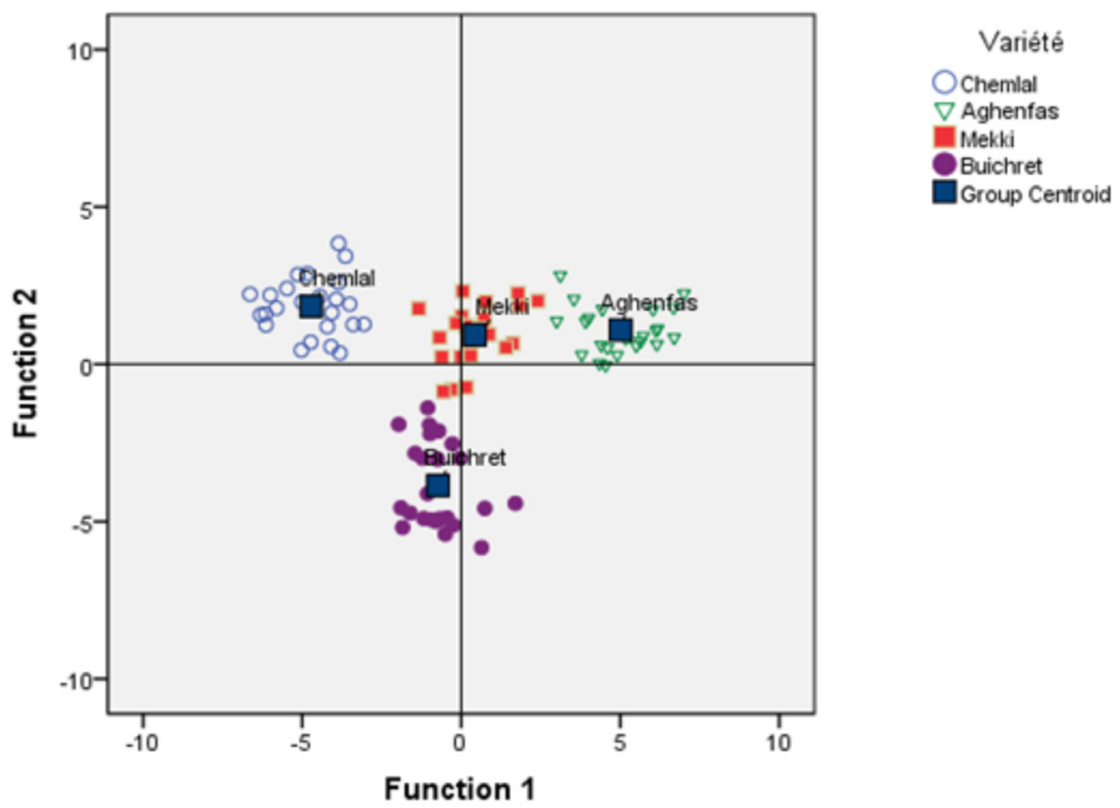

Fig. 4. A graphical representation of a discriminant function analysis on sterolic and alcoholic compounds of the four varieties: Aghenfas, Buichret, Chemlal and Mekki.

Principal component analysis (PCA) on the compositional data was not effective in visualizing possible groups of olive oil varieties. While, LDA showed that the cultivars can be adequately distinguished on the basis of sterolic and alcoholic compositions. The results of this study provide important data, which can be employed in olive oil authenticity studies in Algeria. Finally, additional analysis should be performed for a better characterization of Algerian olive heritage.

\section{References}

Abuajah CI, Ogbonna AC, Osuji CM. 2015. Functional components and medicinal properties of food: a review. J Food Sci Technol 52(5): 2522-2529.

Aparicio R, Conte LS, Fiebig H. 2013. Olive oil authentication. In: Aparicio R, Harwood J, eds. Handbook of olive oil, 2nd ed. Boston, MA: Springer, US, pp. 590-641.

Ben Temime S, Manai H, Methenni K, et al. 2008. Sterolic composition of Chétoui virgin olive oil: influence of geographical origin. Food Chem 110: 368-374.

Bengana M, Bakhouche A, Lozano-Sánchez J, et al. 2013. Influence of olive ripeness on chemical properties and phenolic composition of Chemlal extra-virginoliveoil. Food Res Int 54: 1868-1875.

Bianchi G. 2003. Lipids and phenols in table olives. Eur J Lipid Sci Tech 105: 229-242.

Christopoulou E, Lazarak, M, Alexiou F, Synouri S, Frangis-Cos E. 1996. Influence of certain factors on the composition of olivepomace oils. Part II sterol, triterpenic dialcohols and aliphatic alcohols. Rev Ital delle Sostanze Grasse LXXIII: 201-211.

Cilla A, Attanzio A, Barberá R, Tesoriere L, Livrea MA. 2015. Antiproliferative effect of main dietary phytosterols and $\beta$-cryptoxanthin alone or combined in human colon cancer Caco-2cells through cytosolic $\mathrm{Ca}^{+2}$ and oxidative stress- induced apoptosis. J Funct Foods 12: 282-293.
Desouky IM, Haggag LF, Abd El-Migeed MMM, El-Hady ES. 2009. Changes in some physical and chemical properties of fruit and oil in some olive oil cultivars during harvesting stage. World J Agric Sci 5(6): 760-765.

Douzane M, Nouani A, Dako E, Bellal M. 2012. Influence of the variety, the crop year and the growing on the fatty acid and tocopherols composition of some Algerian virgin olive oils. Afr $J$ Agric Res 7(34): 4738-4750.

El Antari A, Hilal A, Boulouha B, El Moudni A. 2000. Estudio de la influencia de la variedad, los factores ambientales y la tenicas de cultivo en las caracteristicas de los frutosy la composición química del aceite de oliva virgen extra de Marruccos. Olivae 80: 29-36.

European Union Commission. 2011. Commission regulation (EU) No. 61/2011 of 24 January 2011 amending regulation (EEC) No. $2568 / 91$ on the characteristics of olive oil and olive-residue oil and on the relevant methods of analysis.

Fernández-Cuesta A, León L, Velasco De la Rosa R. 2013. Changes in squalene and sterols associated with olive maturation. Food Res Int 54(2): 1885-1889.

Field A. 2009. Discovering Statistics Using SPSS, 3rd ed. London: Sage Publications Ltd, p. 384.

Giacalone R, Giuliano S, Gulotta E, Monfreda M, Presti G. 2015. Origin assessment of EV olive oils by esterified sterols analysis. Food Chem 188: 279-285.

Giuffrè AM. 2014. Evolution of fatty alcohols in olive oils produced in Calabria (Southern Italy) during fruit ripening. J Oleo Sci 63(5): 485-496.

Grati-Kammoun N, Zarrouk N. 2012. Exploratory chemometric analysis for the characterisation of Tunisian olive cultivars according to their lipid and sterolic profiles. Int J Food Sci 47(7): 1496-1504.

Gutiérrez F, Jimenez B, Ruíz, A, Albi MA. 1999. Effect of olive ripeness on the oxidative stability of virgin olive oil extracted from the varieties Picual and Hojiblanca and on the different components involved. J Agric Food Chem 47(1): 121-127. 
Gutiérrez F, Varona I, Albi MA. 2000. Relation of acidity and sensory quality with sterol content of olive oil from stored fruit. J Agric Food Chem 48: 1106-1110.

Haddadi M, Yakoub-Bougdal S. 2010. Olive rootstock production from Olea europea var. Chemlal cultured in vitro. Cah Agric 19: 288-291.

International Olive Council (IOC). 2016. Trade standard applying to olive oils and olive-pomace oils. COI/T.15/NC No 3/Rev.11, p. 16.

Krichène D, Allalout A, Salvador MD, Fregapane G, Zarrouk M. 2010. Fatty acids, volatiles, sterols and triterpenic alcohols of six monovarietal Tunisian virgin olive oil. Eur J Lipid Sci Tech 112: 400.

Lazzez A, Perri E, Caravita MA, Khlif M, Cossentini M. 2008. Influence of olive maturity stage and geographical origin on some minor components invirgin olive oil of the Chemlali variety. J Agric Food Chem 56: 982-988.

Lukić M, Lukić I, Krapac M, Sladonja B, Pilizota V. 2013. Sterols and triterpene diols in olive oil as indicators of variety and degree of ripening. Food Chem 136: 251-258.

Mahaddalkar T, Suri C, Naik PK, Lopus M. 2015. Biochemical characterization and molecular dynamic simulation of $\beta$-sitosterol as a tubulin-binding anticancer agent. Eur $J$ Pharmacol 760: $154-162$.

Manai-Djebali H, Krichéne D, Ouni Y, Gallardo L, Sànchez J, Osorio E. 2012. Chemical profiles of five minor olive oil varieties grown in central Tunisia. J Food Compos Anal 27: 109-119.

Mariani C, Fedeli E, Grob K, Artho A. 1991. Indagine sulle variazioni dei componenti minori liberied esterificati di oli ottenuti da olive in funzione della maturazione e dello stoccaggio. Riv Ital delle Sostanze Grasse 68(4): 179-188.
Martinez Suarez JM. 1973. Recientes estudios de la almazara experimental delinstituto de la grasa. Riv Ital delle Sostanze Grasse 50: 325-330.

Mendil M, Sebai A. 2006. L'olivier en Algérie. Alger : Institut technique de l'arboriculture fruitière et de la vigne, pp. 26-97.

Ministry for Agriculture and the Rural Development (MADR). 2014. Report of the ministry for agriculture and the rural development. Development program of olive cultivation, 2010/2014.

Monfreda M, Gobbi L, Grippa A. 2012. Blends of olive oil and sunflower oil: Characterisation and olive oil quantification using fatty acid composition and chemometric tools. Food Chem 134(4): 2283-2290.

Rivera del Álamo RM, Fregapane G, Aranda F, Gómez-Alonso S, Salvador MD. 2004. Sterol and alcohol composition of Cornicabra virgin olive oil: the campesterol content exceeds the upper limit of 4\% established by EU regulations. Food Chem 84: 533-537.

Rossell JB. 2001. Frying: Improving quality. Boca Raton, FL: CRC Press.

Sánchez-Casas J, Osorio Bueno E, Montaño García AF, Martinez Cano M. 2004. Sterol and erythrodiol + uvaol content of virgin olive oils from cultivars of Extremadura (Spain). Food Chem 87: 225-230.

Uceda M, Hermoso M. 2001. La calidad del aceite de oliva. In: Barranco D, Fernández-Escobar R, Rallo L, eds. El cultivo del olivo. Madrid, Spain: Mundi Prensa, pp. 589-614.

Vekiari SA, Oreopoulou V, Kourkoutas Y, Kamoun N, Msallem M, Psimouli V, Arapoglou D. 2010. Characterization and seasonal variation of the quality of virgin olive oil of the Throumbolia and Koroneiki varieties from Southern Greece. Grasas Aceites 61: 221-231.

Yorulmaz A, Erinc H, Tekin A. 2013. Changes in olive and olive oil characteristics during maturation. J Am Oil Chem Soc 90: 647-658.

Cite this article as: Boulkroune H, Lazzez A, Guissous M, Bellik Y, Smaoui S, Kamoun NG, Madani T. 2017. Characterization of sterolic and alcoholic fractions of some Algerian olive oils according to the variety and ripening stage. OCL 24(5): A502. 